\title{
Menjadi Modern dan Religius: Perguruan NU di Blitar 1950an-1970an
}

\author{
Saiful Hakam ${ }^{1}$ \\ ${ }^{1}$ Lembaga Ilmu Pengetahuan Indonesia \\ Email: ${ }^{1}$ hajikabid@gmail.com
}

\begin{tabular}{l}
\hline Tersedia Online di \\
http://www.jurnal.unublitar.ac.id/ \\
index.php/briliant
\end{tabular}

Sejarah Artikel

Diterima pada 13 November 2017

Disetuji pada 13 November 2017

Dipublikasikan pada 13

November 2017 Hal. 544-553

\section{Kata Kunci:}

modern, religius, perguruan nu

\section{DOI:}

http://dx.doi.org/10.28926/briliant .v2i4.119

\begin{abstract}
Abstrak: Kajian ini merupakan kajian pustaka. Hal yang diutamakan ialah pembacaan penuh atas buku-buku yang membahas tentang sepak terjang NU di ranah agama, politik, sosial, dan ekonomi. Selain itu, penelitian ini adalah penelitian historis. Hasil Kajian menunjukkan perguruan NU berusaha membangun umat. Perguruan NU berusaha membangun kader-kader terbaik NU dengan cara mendidik para santri menjadi modern dan memiliki pengetahuan umum yang luas dan mendapatkan ijasah negara. Beberapa dari alumni kemudian melanjutkan pendidikan sekolah menengah hingga perguruan tinggi khususnya IAIN. Setelah lulus banyak dari mereka yang kemudian duduk sebagai birokrat di Kementerian Agama di tingkat lokal, regional, maupun pusat
\end{abstract}

Selama ini kajian tentang Nahdatul Ulama (NU) cenderung pada tematema politik. Tentu saja ini tidak mengejutkan karena organisasi kaum santri ini sangat terhubung dalam dinamika politik nasional (Greg Fealy, 2003; Ali Haidar, 1994; Andree Felliard, 1999). Sejak Abdurrahman Wahid menjadi ketua umum PBNU tahun 1984, ada beragam penelitian tentang NU. Kebanyakan tema dari penelitian tersebut mengarah pada keberadaan NU sebagai partai politik, penggerak civil society (Badrun Alaena, 2000) dan sebagai komunitas yang kritis terhadap rezim Orde Baru (Mituso Nakamura, 1997; Andree Felliard, 1999; Martin van Bruinessen, 1994). Dapat dikatakan bahwa Historiografi NU selama ini cenderung pada tema-tema politik besar (Ali Haidar, 1994). Kebanyakan Historiografi NU selama ini berkutat pada tokoh-tokoh besar NU, tentang NU di pentas politik Nasional dan jelas tentang NU di Jakarta.

Greg Fealy menjelaskan bahwa terdapat dua macam model historiografi Nahdlatul Ulama (NU). Pertama, model penulisan yang sangat kritis terhadap NU, dapat dikatakan bahwa model ini didominasi oleh peneliti modernis (Greg Fealy, 2003). Kedua, model penulisan yang menggunakan pendekatan yang lebih simpatik, menghargai dan memahami tradisi budaya NU. Model kedua mengkritisi model pertama bahwa asumsi modernis yang mengabaikan peran NU tersebut disebabkan; pertama, kedangkalan analisa, terutama dalam memahami langkah politik NU yang bersandar pada nilai hukum Islam klasik (Fikih), suatu hal yang tidak dipahami dengan baik oleh peneliti kelompok modernis atau Barat. Kedua, penelitian model pertama diawali dengan prasangka negatif, semua pandangan dari kalangan NU dianggap sebagai pembenaran yang hanya memberi bobot keagamaan atas kepentingan NU semata. Lebih jauh, Fealy dalam 
pendahuluan bukunya mengatakan bahwa wacana kritis dalam historiografi NU tersebut merupakan pandangan dari luar NU melalui bentuk pemikiran modernisme Islam dan developmentalisme kapitalis Barat (Greg Fealy, 2003).

Buku karya Greg Fealy berjudul Ijtihad Politik Ulama dapat dikategorikan dalam model penulisan kedua. Buku ini lahir dari pengamatan langsung terhadap tradisi budaya tradisionali Islam yang sangat nyata terwujud dalam kehidupan pesantren (Greg Fealy, 2003). Buku Greg Fealy ini merupakan salah satu historiografi sejarah politik NU yang cukup penting. Pada masa Demokrasi Parlementer dan Terpimpin, keterlibatan NU dalam perpolitikan Indonesia cukup intens dan dominan. Setelah dibubarkannya Masyumi pada 1960an, NU menjadi satu-satunya partai Islam di pemerintahan Demokrasi Terpimpin (Greg Fealy, 2003). Rentang waktu tersebut adalah fase awal bagi kehidupan politik NU yang sesungguhnya. NU melihat bahwa politik adalah sarana utama untuk mengamankan kepentingan keagamaan dan kesejahteraan sosial-ekonomi Muslim tradisional dan para kiai yang memimpinnya.

NU jika dipahami dari tradisi pemikirannya lebih memperlihatkan keluwesan dari pada oportunis. Ben Anderson mengingatkan bahwa peran NU dan Islam Tradisonal sangat signifikan dalam berbagai perubahan sosial-politik di Indonesia (Greg Fealy, 2001). Menurut Ben ada prasangka ilmiah yang selama ini mendominasi pemikiran peneliti Barat dan Islam Modernis. Mereka menganggap bahwa NU menggunakan agama untuk tujuan politis, padahal sebaliknya, NU selalu menggunakan politik untuk mencapai tujuan Islam.

Namun demikian, NU bukanlah sekedar Pengurus Besar NU dengan kiaikiai besar yang terkenal di tingkat nasional (Syamsuddin Haris, 1990). NU bukan sekedar tentang Kiai Haji Hasjim Asyari, Kiai Haji Wahab Hasbullah, Kiai Wahich Hasjim (uhammad Rifai, 2009), Kiai Haji Idham Chalid, Subhan Z.E. NU bukanlah sekedar tentang sosok Gus Dur, tokoh-tokoh utama NU selama hampir dua puluh tahun berperan penting dalam membawa NU sebagai kekuatan politik yang diperhitungkan (Greg Barton, 2002; Ismail Faisal, 1999; Daniel Dhakidae, 1994). Di sini saya ingin mengatakan bahwa NU juga bersifat plural. Di sini saya ingin mengatakan bahwa ada beragam kelompok di dalam NU. Jelas ada perbedaan karakter yang besar antara NU Sulawesi Selatan di mana orang-orang Makassar, para pedagang besar antar pulau sangat dominan dengan NU Jawa Timur di mana orang Jawa, para tuan tanah sangat dominan. NU Sulawesi Selatan cenderung berafiliasi pada Golkar sedangkan NU Jawa Timur cenderung berafiliasi pada PKB. Maka, Jelas ada perbedaan antara Ke-NU-an Jusuf Kalla seorang Makasar asli, pengurus NU Sulawesi Selatan dengan Abdurrahman Wahid seorang NU Jawa Timur, seorang kiai dengan basis materi yang setara dengan pemilik sawah di Jombang. Sesungguhnya, NU dari sudut pandang profesi atau basis materi pendukungnya, dan identitas kedaerahan adalah sangat beragam. Dengan kata lain, pembahasan tentang NU lokal, tentang Sejarah NU di tingkat lokal selama ini sangatlah miskin. Padahal, di daerah-daerah NU juga menorehkan sejarah.

\section{METODE}

Kajian ini merupakan kajian pustaka. Hal yang diutamakan ialah pembacaan penuh atas buku-buku yang membahas tentang sepak terjang NU di ranah agama, politik, sosial, dan ekonomi. Kajian tentang NU di bawah 
kepemimpinan Abdurahman Wahid sangat menarik karena figurnya yang sangat kontroversial karena membela dan melindungi kaum minoritas, mendukung dialog antar umat beragama, bersahabat akrab dengan pemimpin agama Katholik, Budhha, dan Tionghoa. Studi pustaka menunjut kejelian dalam membaca data dan konteks. Selain itu, penelitian ini adalah penelitian historis. Tujuannya adalah untuk mendapatkan data-data detil. Dengan metode etno-historis wawancara dengan tokoh-tokoh perguruan NU di Blitar terutama di kampung-kampung basis santri di kota Blitar yakni Kauman, Sukorejo dan Plosokerep. Dari tiga kampung inilah tokoh NU yang mendidirikan Perguruan NU berasal. Selain itu, ada wawancara alumni-alumni perguruan NU di Blitar dan menggunakan data-data seperti foto, ijazah dan buku pelajaran sekolah.

\section{HASIL}

Blitar adalah sebuah kota kecil di pedalaman Jawa Timur, dari Surabaya ibukota Propinsi Jawa Timur, kira-kira lima jam dengan mengendari mobil atau sekitar $120 \mathrm{~km}$. Di Kota ini, tepatnya di tengah kota, pada tahun 1960 hingga 1980-an berdiri sebuah lembaga pendidikan modern, pada saat itu, untuk kaum muda NU. Perguruan NU adalah sebuah lembaga pendidikan di mana di dalamnya terdapat dua sekolah menengah penting yakni Madrasah Tsanawiyah dan Sekolah Mengah Umum.

Perguruan NU di Blitar muncul dan berkembang pesat pada era tahun 1950-an hingga 1970-an. Kemunculannya memperlihatkan perubahan-perubahan semangat kemajuan dalam keagamaan komunitas NU Blitar. Kemunculannya memperlihatkan bahwa komunitas NU bersikap adaptif dalam menghadapi perubahan sosial. Dari sisi tradisi keagamaan NU, Perguruan NU adalah lembaga pendidikan modern sehingga menjadi sesuatu yang sangat radikal di lingkungan NU di masa itu. Ini berarti bahwa, dinamika NU sebagai organisasi politik ditopang oleh lembaga pendidikan modern yang mempersiapkan kader-kader terbaik dengan beragam profesi. Lembaga ini juga menjadi tanda bahwa di dalam tubuh NU di tingkat lokal sekalipun kelompok muda sangat dinamis dalam berfikir dan sangat aktif bergerak. Ini berarti bahwa di tubuh NU selalu terjadi dialektika dalam ide dan praktik. Sekelompok anak muda ini berusaha membangun umat di dalam lingkungannya terutama mempersiapkan kader terbaik untuk melindungi dan menjaga tradisi-tradisi keagamaannya yang sangat khas.

\section{PEMBAHASAN}

Dalam konteks pendidikan secara umum, NU sejatinya adalah organisasi yang bergerak di bidang pendidikan. Basis NU adalah pondok pesantren lengkap dengan barisan kiai yang punya kekuatan spiritual dan institusional di dalam dinamika NU (Shiddiqi, Nourouzzaman, 1975; Martin Van Bruinessen, 1994, 1999). Namun, banyak kajian lebih memusatkan perhatian pada dinamika NU di bidang politik dari pada pendidikan. Padahal jika diperhatikan dengan lebih detail dan dengan sudut pandang etnografis maka boleh dikatakan bahwa NU di tingkat nasional terutama dinamika PBNU tentu saja sangat bercorak politik. Namun di tingkat lokal terutama jaringan kantor-kantor cabang di semua kota dan kabupaten di Pulau Jawa, NU adalah organisasi yang teguh bergerak di bidang pendidikan. Di satu sisi ada jaringan pondok pesantren yang sangat mandiri di bawah naungan 
jaringan kekerabatan para kiai. Di sisi lain terdapat jaringan sekolah dan madrasah di bawah naungan LP Maarif.

Meskipun NU berbasis pendidikan tradisi di mana pondok pesantren dan barisan kiai sebagai inti dan pusatnya namun jangan dilupakan bahwa NU juga memusatkan perhatian besar pada sekolah dan madrasah di bawah naungan Lembaga Pendidikan Maarif (Andree Felliard, 1999). Ini berarti bahwa di dalam tubuh NU selain pondok pesantren yang berbasis pada tradisi itu juga terdapat madrasah dan sekolah yang bercorak modern karena berusaha mengikuti dengan sungguh-sungguh model-model pendidikan, pedagogi, atau sistem pengajaran modern (Andree Felliard, 1999). Corak pendidikan ini sangat berbeda dengan corak pendidikan tradisi di pondok pesantren.

Salah satu dari model pendidikan modern di dalam tubuh NU ialah perguruan NU Blitar. Dalam sudut pandang historis, kemunculan Perguruan NU Blitar sangat unik karena hadir di tengah-tengah spirit tradisi keagamaan NU yang pada asasnya masih bersikap resisten dan menolak sistem dan model pendidikan modern (Clifford Geertz, 2013, bab Santri). Selain itu, Perguruan NU lahir di sebuah kota dan daerah yang menjadi basis utama dari komunitas-komunitas priyayi dan abangan. PKI dan PNI menguasai panggung politik di kota ini (Raharjo Suwandi, 2000). Sekolah-sekolah modern memiliki basis komunitas yang sangat kuat di kota ini. Perguruan Taman Siswa, Perguruan Pendidikan Katholik dan Sekolah-sekolah umum warisan kolonial yang kemudian berlanjut menjadi Sekolah-sekolah Umum di bawah naungan Pemerintah. Di sisi lain juga terdapat jaringan Perguruan Muhammadiyah yang meskipun kecil namun sangat kuat karena memiliki jaringan-jaringan pendidikan nasional. Murid-muridnya sebagian berasal dari pulau-pulau Sumatera, Kalimantan, dan Sulawesi (Saiful Hakam, 2005).

Dalam pandangan sosiologis, ada tiga hal penting dari Perguruan NU. Pertama, secara sosial, lembaga ini memberikan wadah bagi santri-santri baru dari pelosok desa di Blitar pada waktu itu untuk menempuh pendidikan yang diakui oleh negara. Pada masa awal berdiri, murid-muridnya berasal dari anak-anak dari keluarga-keluarga pengurus ranting, atau pengurus NU di tingkat desa, di seluruh wilayah Blitar. Lembaga pendidikan pendidikan memberikan ruang bagi mereka untuk melihat dan merasakan modernisasi pendidikan. Kedua, sejumlah besar alumni-alumni dari Perguruan NU memperkuat kembali jaringan NU di Departemen Agama dan menjadi elit NU di masa depan (Denys Lombard, 2000). Banyak dari mereka menjadi staf dan guru-guru agama di sekolah-sekolah negeri dan madrasah-madrasah negeri ciptaan pemerintah. Ketiga, lembaga ini melindungi dan mempertahankan ajaran-ajaran NU yakni ahli sunnah wal jamaah.

Selama ini banyak peneliti baik di kalangan NU sendiri maupun non-NU menyebut masa 1952-1984 adalah masa di mana warga NU larut dalam urusan politik (Greg Fealy, 2001). Padahal, dari sudut sejarah lokal NU, masa ini juga menyimpan data-data sejarah tentang dinamika warga muda NU di bidang pendidikan dan keagamaan. Di Blitar, dengan cerdik, kaum muda NU membangun jaringan pendidikan modern di pusat kota untuk menarik santri-santri terbaik di pelosok desa di Blitar dan mencegah mereka masuk ke sekolah Islam modern yang didirikan oleh Muhammadiyah.

Perguruan NU didirikan oleh sekelompok anak muda progresif pada waktu itu. Mereka mencoba membangun jaringan kultural NU. Mereka yang 
mendirikan lembaga pendidikan tersebut adalah sekelompok elit lokal, yakni putra-putra dari elit NU, para kiai, dan tuan tanah kaya yang tinggal di kota dan menikmati fasilitas kota. Meskipun mereka menempuh pendidikan di sekolah Muhammadiyah namun mereka masih menjunjung identitas ke-NU-an. Malah, di sekolah Muhammadiyah identitas NU mereka muncul dan bangkit.

Ide pendirian Perguruan NU adalah sederhana. Tidak ada sekolah NU di Kota Blitar. Akibatnya, santri-santri NU yang hendak melanjutkan pendidikan harus mengambil pendidikan di satu-satunya lembaga pendidikan Islam di kota yakni Perguruan Muhammadiyah. Fakta ini tentu saja kurang menyenangkan bagi kalangan muda NU. Selain itu, pada pertengahan tahun 1960-an, mereka sadar bahwa posisi NU di masa depan akan sangat lemah karena tidak adanya sekolah modern. Mereka beranggapan bahwa pondok pesantren tidak lagi memadai dan cocok. Sistem pendidikan di pondok pesantren tidak sistematis dan tidak mengeluarkan ijazah yang diakui oleh negara. Ini menyulitkan bagai santri-santri terbaik NU untuk duduk di birokrasi dan sektor swasta. Dengan kata lain, mereka sadar bahwa NU sebagai sebuah kelompok masyrakat adalah kelompok masyarakat yang diabaikan oleh sistem dan tidak punya akses pendidikan yang lebih baik.

Selain itu, mereka juga sadar bahwa sulit sekali bagi anak-anak muda NU di masa itu untuk menempuh pendidikan sekolah-sekolah negeri milik pemerintah. Ujian masuk sekolah negeri jelas sangat sulit bagi anak-anak santri yang belum terbiasa membaca huruf latin. Biaya di sekolah negara juga cukup mahal. Meskipun terdapat sekolah-sekolah swasta seperti Muhammadiyah, Taman Siswa, dan Sekolah Katholik, para orang tua dan santri-santri muda enggan masuk ke sekolah-sekolah tersebut. Alasan utama mereka adalah alasan teologis. Mereka takut Ke-NU-an mereka akan hilang. Mereka takut bila anak-anak mereka masuk ke sekolah modern Muhammadiyah maka anak-anak mereka akan beralih menjadi Muhammadiyah. yang tanpa gentar mengkritik NU. Hanya sebagian kecil kalangan elit lokal NU khususnya yang tinggal di kota, memiliki penghasilan ekonomi yang kuat, dan punya pemikiran maju yang berani memasukkan anakanak mereka ke sekolah-sekolah sekuler tersebut.

Dengan alasan inilah maka anak-anak muda NU di Blitar pada waktu itu berniat mendirikan sekolah modern NU. Beberapa tokoh penting pendiri Perguruan NU adalah kaum muda NU dari desa muslim Plosokerep. Plosokerep terletak dua kilometer dari pusat Kota. Desa ini selama beberapa generasi menghasilkan para pemimpin politik Islam yakni Mas Hadji Abdoellah Fakih, President Sarikat Islam dan Machfoed Achmad, Ketua Partai NU Blitar. Banyak elit-elit NU berasal dari desa ini. Kebanyakan dari mereka adalah para haji, tuan tanah yang kaya dengan bagunan rumah yang megah.Mereka adalah Maksum, Dzannuri Acham, Chudori, Muslich dan Tauchid.

Dalam perjalanannya, Perguruan NU berjalan cukup sukses. Secara veritikal lembaga ini sejatinya adalah lembaga pendidikan lokal yang menampung santri-santri terbaik di dalam jaringan pondok-pondok pesantren di Blitar. Secara horizontal, lembaga ini berada di bawah naungan LP Maarif Pengurus Besar Nahdlatul Ulama di Jakarta. Secara geografis, lembaga pendidikan ini berlokasi tepat di tengah kota, berdekatan dengan Masjid Agung Blitar dan Kediaman Bupati Blitar. Lembaga ini juga merekrut guru-guru dari sekolah sekuler untuk menjadi pengajar pelajaran umum seperti aljabar, musik, bilogi dan olah raga. 
Untuk pelajaran agama, lembaga ini juga merekrut para kiai guna mengajarkan ajaran ahli sunnah wal jamaah. Dan yang lebih penting, lembaga ini juga mengajarkan pelajaran khusus $\mathrm{Ke}-\mathrm{Nu}$-an, atau sejarah $\mathrm{NU}$ dan hagiografi para pendirinya. Kesuksesan lembaga ini adalah terletak pada restu kiai dan khususnya pengurus NU Blitar dan sejumlah besar putra dan putri pengurus NU tingkat ranting dari pelosok desa di Blitar menempuh pendidikan di lembaga ini.

Perguruan NU menjadi jembatan bagi santri-santri yang ingin mendapat ijazah resmi dari sekolah. Pada waktu itu, akses pendidikat sangat sulit. Fasilitas, transportasi, dan alat-alat pendidikan sangat terbatas. Dalam masa ini, lembaga pendidikan agama, terutama pesantren, dan sekolah-sekolah agama, dianggap sebagai lembaga swasta dan dianggap sebagai lembaga pendidikan kelas dua. Untuk mendapatkan ijazah negara, siswa-siswa harus bekerja keras mengikuti ujian persamaan yang diadakan oleh negara. Santri-santri yang kemudian mendaftar menjadi siswa di Perguruan NU punya akses untuk mengikuti ujian persamaan yang diadakan oleh Kementerian Pendidikan dan Kebudayaan. Jika santri lulus dalam ujian ini maka ia mendapatkan surat tanda lulus dan berhak melanjutkan pendidikan di bawah naungan Kementerian Pendidikan dan Kebudayaan. Artinya, bagi siswa yang ingin melanjutkan pendidikan dan berkarir di bawah Kementerian Pendidikan dan Kebudayaan, ia harus memiliki ijazah persamaan. Sedangkan, jika siwsa-siswa gagal mengikuti ijazah persamaan atau tidak lulus, maka siswa-siswa itu tetap mendapatkan ijazah dari Perguruan NU. Hal yang menarik, dengan ijazah Perguruan NU, mereka ini punya kesempatan untuk melanjutkan pendidikan di perguruan tinggi di bawah naungan Kementerian Agama yakni IAIN, dan juga berkarir di kantor-kantor kementerian Agama baik di pusat maupun di daerah, sebagai guru agama dan staf birokrasi.

Sedikit sekali pembahasan NU di tingkat lokal. Selama ini para peneliti cenderung melihat NU sebagai sebuah organisasi politik besar berpusat di Jakarta. Padahal, di tingkat lokal NU memiliki peran yang sangat signifikan. Di tingkat lokal, di Blitar, NU bukan hanya sebuah organisasi keagamaan. NU juga menyangkut identitas keislaman. Di Blitar, hingga sekarang, orang tidak cukup mengatakan bahwa saya beragama Islam. Ada pertanyaan lain yang akan muncul, Islam yang mana NU atau Muhammadiyah.

Perguruan NU adalah manifestasi dari identitas keislaman warga NU. Melalui Perguruan NU, Warga NU di Blitar ingin membangun dan mempertahankan ajaran-ajaran NU pada anak-anak mereka. Dengan cara ini, warga NU membangun kader-kader NU di tingkat lokal dan bahkan regional.

Namun, dalam segi dan sudut pandang tradisi keagamaan, pembentukan dan pendirian Perguruan NU adalah program sangat radikal di masanya (Greetz, 2012). Waktu itu resistensi terhadap pendidikan modern yang diselenggarakan oleh negara masih sangat tinggi. Narasi besar, pandangan umum, dan idiologi di kalangan kiai bersikap menentang dan tidak antusias terhadap pendirian sekolah atau madrasah modern di lingkungan warga NU karena mengajarkan pelajaranpelajaran umum. Para kiai NU di masa itu masih dipengaruhi oleh pendoman fatwa yang berasal dari masa kolonial belanda bahwa haram bagi anak-anak NU masuk dan bergabung ke sekolah umum. Para kiai NU juga memberikan fatwa haram bagi warga NU memakai jas, dasi, dan celana, pakaian khas di sekolah modern. Fatwa ini jelas berdasarkan penafsiran para kiai atas dalil-dalil agama 
khususnya Quran dan Hadist namun dalam konteks menentang penjajahan Belanda.

Di tingkat nasional NU memang bisa dipandang sebagai sebuah organisasi keagamaan modern dan kekuatan politik (Arief Affandi, 1997). Namun, ini jelas sangat berbeda di tingkat lokal. Di tingkat lokal, NU kadang menyerupai sebuah agama dan kepercayaan. Bahkan, beberapa penganut NU menyebut Muhammadiyah sebagai bukan Islam. Emha Ainun Najib dengan sangat bagus membuat anekdot tentang hal ini. Ketika seorang pejabat di Sumenep bertanya pada seorang warga, orang Madura, tentang agama di kota tersebut, ia menjawab bahwa 90 persen pendudukanya adalah Islam sisanya Muhammadiyah. Sama halnya di Blitar. Ide pendirian Perguruan NU adalah juga bermula dari identitas NU. Perguruan NU adalah salah satu cara dari warga NU untuk memperkuat kembali identitas ke NU an. Perguruan NU adalah salah satu cara bagi warga NU menjalankan modernisasi.

Dari sudut pandang sosiologis sebenarnya perubahan politik dan sosial membawa pengaruh besar pada sebagian kecil terutama golongan elit perkotaan dari komunitas NU di Blitar untuk mendirikan sebuah lembaga pendidikan baru di luar pondok pesantren. tahun 1950-an ialah tahun-tahun penuh optimis untuk membangun kesadaran politik dan meraih pendidikan dan masa depan baru. Perubahan politik dan sosial mempengaruhi munculnya Perguruan NU. Sebagaimana lazimnya di dalam komunitas NU, basis utama NU Blitar adalah kaum santri, para saudagar, dan para haji yang tak segan menampkkan ketaatan ibadahnya (Denys Lombard, 2008). Perguruan NU muncul sebagai bagian dari semangat baru dari anak-anak Muda NU untuk mengikuti arus semangat kebangsaan, membangun pemerintahan republik yang lebih egaliter, dan mengiss kekosongan ruang pendidikan modern di kalangan komunitas NU. Kaum muda NU di masa itu sadar bahwa pilar NU tidak lagi bisahanya mengandalkan pondok pesantren namun membutuhkan tenaga-tenaga baru yang lebih sesuai dengan jiwa zaman dan punya keahlian-keahlian baru dan profesi-profesi baru di luar tatanan lama di dalam komunitas NU. Relasi antara Perguruan NU dan Kota Blitar sangat erat karena kota Blitar menyediakan ruang dari semangat baru dari bangsa baru dan negara baru yang sedang giat membentuk diri. Hal lain yang jarang diperhatikan, NU di tingkat nasional pada masa itu membentuk organisasiorganisasi otonom antara lain Fatayat, Ansor, IPPNU, dan IPNU. Berdirinya Perguruan NU sejalan dengan perkembangan NU di tingkat nasional. Perguruan NU menyediakan dan mempersiapkan kader-kader terbaik mereka untuk organisasi-organisasi otonom di tingkat cabang dan daerah. Maka, dalam segi pengajaran komunitas, Perguruan NU muncul untuk melindungi tradisi beragama orang-orang NU yang gigig mempertahankan dan melestarikan mazhab dan tradisi tarekat.

Peguruan NU Blitar memberikan narasi berbeda tentang NU. Komunitas berbasis agama ini tidak statis seperti yang dibayangkan sebaliknya sangat dinamis (Martin van Brinessen, 1994). Kaum muda membentuk lembaga, institusi, dan sistem pengajaran baru. Mereka bersungguh-sungguh mempersiapkan generasi, kader, dan anggota baru di dalam NU. Di sini komunitas sebaga entitas dan agama sebagai spirit bergerak timbal balik dan saling mempengaruhi. Di sini tradisi keagamaan, Ke-Nu-an, tidak ditinggalkan sebaliknya dilestarikan menjadi penggerak sosial. Di sini tradsi keagaman 
membentuk dinamika sosial baru. Di sini diasumsikan bahwa pertama Perguruan NU muncul didasarkan pada karakter beragama orang NU yang teguh memegang tradisi, menghormati kiai, dan kitab kuning (Martin van Bruinesse, 1994, 1999). Kedua, Perguruan NU muncul untuk mempersiapkan generasi-generasi baru NU yang lebih siap menerima perubahan dan peluang dari pemerintahan baru.

Dalam konteks historis kemunculan NU adalah bagian dari dinamika di dalam komunitas muslim agraris Jawa karena menghadapi perubahan-perubahan sosial dan ekonomi (Denys Lombard, 2008). Munculnya NU dapat ditafsirkan sebagai suatu cara dari suatu komunitas muslim untuk menampilkan dirinya di hadapan dunia modern seperti Runtuhnya Turki Usmani, Pemerintah Kolonial Belanda dan Sistem Kapitalisme, dan Munculnya Negara-Bangsa Indonesia. Kemunculan NU adalah juga satu cara dari masyarakat Islam agraris menampilkan bentuk-bentuk keagamaan mereka. Memang, latar belakang elit-elit NU di tingkat lokal khususnya di Blitar adalah para haji dan tuan tanah atau petani kaya. Meskipun memang beberapa dari mereka ada yang berpr ofesi sebagai pedagang namun basis utama materi atau ukuran kekayaan mereka adalah masih pada kepemilikan tanah. Dalam kenyatannya memang, beberapa sponsor-sponsor ritual keagamaan maupun pendidikan agama seperti pesantren, di kalangan warga NU adalah para tuan tanah dan petani kaya.

Dari sini bisa dikatakan bahwa Perguruan NU adalah cara cerdik orangorang NU untuk beradaptasi dengan kehidupan modern pada saat itu. Adaptasi ini berjalan lambat, sangat jauh dibandingkan dengan Muhammadiyah, karena adaptasi ini melibatkan banyak perubahan dalam karakter dan semangat agama. Beberapa keluarga-keluarga NU terutama kalangan elit, dan ini sangat sedikit sekali, berpandangan radikal karena tidak menyekolahkan anak-anak ke pesantren sama sekali. Ini adalah asumsi yang masih perlu dibuktikan dalam penelitian ini. Sebagian dari anak-anak dari tokoh-tokoh NU tidak menempuh pendidikan pesantren namun masuk ke sekolah-sekolah umum. Sebagai contonh adalah riwayat hidup seorang putra seorang kiai NU Blitar bernama Mas'oed Machfoedz. Ayahnya Kiai Machfoedz mendorongnya masuk ke sekolah umum dari sekolah dasar hingga perguruan tinggi. Karena itu, ia tidak pernah menempuh pendidikan pondok pesantren sama sekali. Selain itu, ia juga tidak pernah terlibat dalam berbagai organisasi di bawah naungan NU seperti IPNU, Ansor, dan PMII. Namun, setelah pendidikannya berhasil dan karirnya sukses, ia menjadi dosen dan birokrat di universitas besar di Yogyakarta, ia kemudian diminta dan didaulat kiaikiai di Yogyakarta untuk menjadi pengurus wilayah NU di Yogyakarta. Almarhum adalah seorang guru besar akuntasi terkemuka di Indonesia dan pernah menjadi wakil Rektor. Meskipun demikian, Kemunculannya sebagai Ketua PWNU Yogyakarta menjelaskan bahwa jati diri NU begitu melekat dan tidak bisa hilang di dalam dirinya. Ada nuansa pengabdian dan tugas spiritual untuk mengabdi kepada NU dan Para Kiai. Namun, di beberapa pertemuan NU ia sering mengatakan bahwa "saya dulu ingin masuk IAIN, namun oleh bapak saya dilarang karena orang NU itu belum cakap dan tidak bisa dagang, maka saya disuruh masuk ke Sekolah Ekonomi.

\section{KESIMPULAN}

Perguruan NU berusaha membangun umat. Perguruan NU berusaha membangun kader-kader terbaik NU dengan cara mendidik para santri menjadi

551 BRILIANT: Jurnal Riset dan Konseptual Volume 2 Nomor 4, November 2017 
modern dan memiliki pengetahuan umum yang luas dan mendapatkan ijasah negara. Beberapa dari alumni kemudian melanjutkan pendidikan sekolah menengah hingga perguruan tinggi khususnya IAIN. Setelah lulus banyak dari mereka yang kemudian duduk sebagai birokrat di Kementerian Agama di tingkat lokal, regional, maupun pusat.

\section{SARAN}

Penelitian ini mendiskripsikan tentang perkembangan perguruan NU masa tahun 1950-1970. Penelitian ini bisa menjadi referensi bagi pembaca yang memang tertarik dengan perkembangan perguruan NU di Blitar secara khusus. Namun, penelitian ini adalah penelitian permulaan. Sehingga untuk peneliti selanjutnya penelitian ini masih perlu dikembangkan lebih lanjut.

\section{DAFTAR RUJUKAN}

Afandi, Arief (ed.). 1997. Islam Demokrasi Atas Bawah: Polemik Strategi Perjuangan Umat Model Gus Dur dan Amien Rais. Yogyakarta: Pustaka Pelajar.

Alaena, Badrun. 2000. NU, Kritisisme dan Pergeseran Makna Aswaja. Yogyakarta: Tiara Wacana.

Ali, Fachry \& Iqbal Abdul Rauf Saimima. 1991. Analisa Kekuatan Politik Di Indonesia. Jakarta: LP3ES.

Anam, Choirul. 1999. Pertumbuhan dan Perkembangan NU. Surabaya: Bisma Satu.

Andrain, Charles F. 1992. Kehidupan Politik dan Perubahan Sosial. Yogyakarta: Tiara Wacana.

Azra, Azyumardi. 2002. Kasus PKB-NU Kegagalan Politik Islam. Majalah Nahdlatul Ulama AULA. 07-XXIV.

Bruinessen, Martin Van. 1994. Tradisi, Relasi-relasi Kuasa, Pencarian Wacana Baru. Yogyakarta: LKiS.

Clifford Geertz. 2012. Agama Jawa, Abangan Santri Priyayi. Jakarta: Komunitas Bambu.

Denys Lombard. 2008. Nusa Jawa Silang Budaya Jaringan Asia Bagian II. Jakarta: PT Gramedia.

Dhofier, Zamakhsyari. 1982. Tradisi Pesantren: Studi tentang Pandangan Hidup Kyai. Jakarta: LP3ES.

Duverger, Maurice. 1989. Sosiologi Politik, terj. Daniel Dhakidae, cetakan Keempat, Jakarta: Rajawali Pers.

Ellyasa K.H. Darwia (ed). 1994. Gus Dur dan Masyarakt Sipil, Yogyakarta: LKiS.

Greg Fealy \& Greg Barton (ed). 1987/ Tradisionalisme Radikal Persinggungan Nahdlatul Ulama-Negara. Yogyakarta: LKiS.

Gaffar, Afan. 2000. Politik Indonesia: Transisi Menuju Demokrasi, Yogyakarta: Pustaka Pelajar.

Haidar, M. Ali. 1994. Nahdlatul Ulama dan Islam di Indonesia Pendekatan Fikih dalam Politik. Jakarta: PT. Gramedia Pustaka Utama.

Haris, Syamsuddin. 1990. NU dan Politik: Perjalanan Mencari Identitas. Jakarta: PT. Gramedia Pustaka Utama. 
Herson, Lawrence J.R. 1984. The Politics of Ideas Political Theory and American Public Policy. Illinois: The Dorsey Press. 1997. Identitas Politik Umat Islam. Bandung: Mizan. 1999. Islam, Demokratisasi dan Perkembangan Civil Society. Jakarta: Erlangga.

Ismail, Faisal. 1999. NU, Gus Durisme dan Politik Kiai. Yogyakarta: PT. Tiara Wacana.

Johnson, Doyle Paul. 1986. Teori Sosiologi Klasik dan Modern, Jilid I, terj. R.M.Z. Lawang, cetakan Pertama. Jakarta: Gramedia.

Karim, Gaffar. 1995. Metamorfosis, NU dan Politisasi Islam Indonesia. Yogyakarta: LKiS.

. Kembali Ke Situbondo? Sikap NU Terhadap Kepresidenan Gus Dur. Jurnal Gerbang. 12-V. 1999. Kitab Kuning Pesantren dan Tarekat: Tradisi-tradisi Islam di Indonesia. Bandung: Mizan.

Maridjan, Kacung. 1992. Quo Vadis NU Setelah Kembali Ke Khittah 1926. Jakarta: Penerbit Erlangga.

Muhammad Rifai. 2009. Wahid Hasyim Biografi Singkat 1914-1953. Yogyakarta: Garasi.

Mulkhan, Abdul Munir. 1989. Perubahan Perilaku Politik dan Polarisasi Ummat Islam 1965-1987 Dalam Perspektif Sosiologis. Jakarta: Rajawali Persada.

Noeh, Munawar Fuad \& Mastuki HS. 1999. Menghidupkan Ruh Pemikiran KH. Ahmad Siddiq. Jakarta: Logos.

1999. NU Visa a Vis Negara: Pencarian Isi, Bentuk dan Makna, Yogyakarta: LKiS.

Raharjo Suwandi. 2000. A Quest For Justice The Millenary Aspirations of a Contemporary Javanese Wali, Leiden, KITLV Press.

Saiful Hakam. 2005. Langgar Tua dan Pohon Sawo, Sejarah Sosial Politik Plosokerep 1911-1970, Skripsi tidak diterbitkan. Universitas Gadjah Mada, Yogyakarta.

Shiddiqi, Nourouzzaman. 1975. The Role of the 'Ulama' During the Japanese Occupation of Indonesia (1942-45), Tesis tidak diterbitkan. McGill University, Montreal Canada. 